\title{
WHETHER CONTROL OF CORRUPTION MATTERS FOR HAPPINESS: EVIDENCE FROM PANEL DATA ANALYSIS
}

\section{DOI: 10.17261/Pressacademia.2018.921 \\ PAP- V.7-2018(74)-p.381-387}

Elma Satrovic ${ }^{1}$, Ozge Cetiner ${ }^{2}$, Adnan Muslija ${ }^{3}$

${ }^{1}$ Cag University, Yaşar Bayboğan Kampüsü Adana-Mersin Karayolu üzeri 33800, Yenice/Mersin, Turkey. elmasatrovic@cag.edu.tr, ORCID: 0000-0002-8000-5543

${ }^{2}$ Cag University, Yaşar Bayboğan Kampüsü Adana-Mersin Karayolu üzeri 33800, Yenice/Mersin, Turkey. ozgecetiner@cag.edu.tr, ORCID: 0000-0003-0790-1242

${ }^{3}$ University of Sarajevo, Hazima Dedica 15b, Visoko, Bosnia and Herzegovina. adnanmuslija@msn.com, ORCID: 0000-0002-8176-6600

To cite this document

Satrovic, E., Cetiner, O., Muslija, A. (2018). Whether control of corruption matters for happiness: evidence from panel data analysis. PressAcademiaProcedia (PAP), V.7, p.381-387.

Permemant link to this document: http://doi.org/10.17261/Pressacademia.2018.921

Copyright: Published by PressAcademia and limited licenced re-use rights only.

\section{ABSTRACT}

Purpose- Paper aims to give empirical evidence on the impact of control of corruption on happiness as a proxy of social progress by collecting panel data for 59 countries over the period 2007-2016.

Methodology- Initial as well as extended model that controls for government consumption are estimated using linear static and dynamic panel data estimators. In order to test for the sensitivity of the results and to estimate short- and long-run coefficients, panel ARDL framework is employed.

Findings- The results of linear static and dynamic panel data estimators indicate the significant positive impact of control of corruption on happiness in both, initial and extended models. ARDL model reports a significant relationship between control of corruption and happiness in initial and extended model only in the long-run.

Conclusion- The convergence process from corrupt to hones politics is complex and is likely to be achieved only in the long-run period.

Keywords: ARDL, control of corruption, happiness, panel, social progress.

JEL Codes: C23, 017, D73

\section{INTRODUCTION}

Many countries in the world, especially developing, pay special attention to the corruption since it tends to have a devastating impact on the society as a whole. This is why many world institutions try to define the corruption. To mention a few, World Bank and UNDP define corruption as "the misuse or the abuse of public office for private gain". Moreover, Aidt (2009) defines corruption as "sale of government property for private gain". In addition, it is important to emphasize that the corruption is present and varies among all countries of the world. This is why all governments at any level need to deal with this issue.

The problem of corruption is very common all over the world irrespective to the way of governance or social model. It occurs in developed as well as developing countries due to the opposing power of authority and private interest. Therefore, the danger of corruption became attractive issue of debate in recent years.

Popova and Podolyakin (2014) indicate that the original of the corruption lies in inefficient management. Inefficient management tends to increase wrong public relations that finally cause new problems in society and decrease happiness and social progress (Weder, 2002). This author also indicates that in the case of corruption, people find themselves in institutional trap - the situation when deviation from the standard behavior prevailing in the society can result in worse position of rebel: without giving the bribe the person does not receive the benefit, and so on. In the case when corruption is present at every level of society, it tends to become a standard way of behaving since the cost of corruption is lower than the price to control or resolve it. As a result, many countries in the world just point out the existence of the problem of corruption but can do nothing to deal with this issue.

Control of corruption is one of the dimensions of good governance. However, corruption and governance are opposing forces since the aim of the good governance is to serve the interest of the society as a whole while the corruption aims to serve the interest of one individual or small number of individuals. Moreover, bounding rules aim to create a government that is accountable as well as transparent. On the other hand, corruption plays on these rules in order to benefit small number of individuals (Balboa and Medalla, 2006). Authors have also indicated that corruption has very negative impact on national psyche which can destruct the already established and well- functioning 
system of governance. In the case when the society is continuously exposed to the corruption, the perception of people of what is right or wrong slightly changes and leads to the decrease in happiness and social progress.

Corruption appears under the conditions explained by Klitgaard (1998). The author indicates that monopoly of power, when combined with discretion and absence of accountability, will result to corruption. However, it is important to emphasize that corruption does not necessarily state forever. It is possible to converge from corrupt to hones politics. Paldam (2002) indicates that the convergence process is difficult and long one.

Taking into account aforementioned, economist agree that corruption represents a major obstacle to development, social progress and happiness of some society. In addition, Blackburn et al. (2006) indicate that corruption tends to lower income and is one of the most important generators of poverty.

This paper takes a critical look at the link between the control of corruption and happiness. The analysis centers on whether corruption is sanding or greasing the wheels of social progress. The rest of the paper proceeds as follows. In Section 2, we review the literature and give theoretical arguments regarding the relationship between control of corruption and social progress. In Section 3, we describe the data, variables and methodology. In Section 4, we present empirical evidence on the matter. Finally, we conclude in Section 5.

\section{LITERATURE REVIEW}

Corruption is defined as abuse of public wealth for private interests by a particular class of people. It has several forms such as nepotism, secretly funding of political parties, close and endangered tie between political elites and business world, bribery in public sector etc. Two opposing views regarding the corruption-economic growth and corruption-social progress can be found in literature. Although some researchers focus on the desirable side of corruption that is accepted as a kind of tax for making government services more efficient and removing established rules' barriers in front of the entrepreneurs, empirical studies show the negative effects of corruption such as increase of income inequality, poverty and budget deficit, decrease of investments, decline in the efficiency of public spending, breaking on political legitimacy and hindrance of the democratic development in the long term etc. Voskanyan (2000) examines the negative effects of corruption on the society as a whole in Armenia. The author indicates several reforms, such as reforms on judiciary system, tax, etc. to reduce corruption. However, among reforms the author indicates that the best reform for Armenia is to have the free and fair elections, to have citizens who know political rights, and incorrupt leader.

In the beginning of 21st century, empirical research of corruption's effects on the different spheres of people's lives has been increased. Popova and Podolyakina (2014) examine the corruption- social system relations and impact of corruption on national economy growth and social development during the period 2005-2011 with the division of countries in the context of adopted social models functioning in the European Union. These are Scandinavian Model, Anglo-Saxon Model (or Liberal Model), Continental European Model (or Conservative Model), Mediterranean Model (or Subsidiary Model). The methodology used includes qualitative content-analysis, comparison, methods of grouping, statistical analysis, correlation and regression analysis. The results indicate that the functioning social systems sphere such as healthcare and education is a kind of investment to human capital development that affects national economy and overall social development.

Fereidouni et al. (2013) analyze the effects of governance issues on happiness and relations between unhappiness and political unrest by using panel data on 14 Middle East and North Africa (MENA) countries, during the period of 2009-2011. The aim of the study is to show the effects of governance components (voice and accountability, political stability and absence of violence, government effectiveness, regulatory quality for private sector development, rule of law and control of corruption) on happiness. Happiness score taken from the World Database of Happiness is used as a proxy variable of happiness. The study finds that although governance components and happiness have direct relations, voice and accountability, regulatory quality and control of corruption variables' are not found to be significant determinants of happiness.

Kéita (2011) explores the determinants and implications of corruption, its impact on economic growth and social progress within 23 OECD countries. The authors have used random and GLS estimators. The main finding of this empirical study is that corruption tends to decrease economic growth and create an economic problem and dissatisfaction of citizens. Similar results are obtained in Aidt (2009). The author indicates that the corruption and economic growth have inverse ratio relations. Shera et al. (2014) report negative effects of corruption on economic growth within the sample of 22 developing countries, in the period between 2001- 2012 by using panel data.

The corruption caused by state capitalism during the US' history, led to the Progressive Movement over the period 1880-1930. It has included demand about administrative (transparency, public management, accountability, professional civil service etc.) and political reforms (Knott, 2012). Achievements on these issues, deregulation of industry and key leaders in US led to the improvement on economy and democracy. As an outcome of these reforms, they succeeded to reduce corruption and increase social progress.

Clark et al. (2014), who examine the relationship between happiness and economic growth. The results indicate that GDP growth does even out the expansion of level of subjective well-being. In spite of theoretical studies, empirical findings show that corruption has clearly negative impact on economic growth, social progress and happiness of the society as a whole. 


\section{DATA, VARIABLES AND METHODOLOGY}

\section{Data and variables}

In order to investigate the relationships between control of corruption and happiness, there was a need to select appropriate proxy variables. Several authors as well as different organizations in the world are making a great effort to measure corruption. For this purpose different indicators based on the results of survey responses are constructed. These indices, typically, measure corruption by asking respondents in some country regarding their attitude towards the likelihood that government officials would demand bribes. Aidt (2009) indicates that the three most popular indicators of corruption are perception index constructed by Transparency International; the corruption index from the International Country Risk Guide; and the control of corruption indicator from the World Bank. The last one is considered appropriate in this paper.

The World Bank indicates that control of corruption captures perceptions of the extent to which public power is exercised for private gain, including both petty and grand forms of corruption, as well as "capture" of the state by elites and private interests. Estimate gives the country's score on the aggregate indicator $(C C)$, in units of a standard normal distribution, i.e. ranging from approximately -2.5 to 2.5 .

On the other hand, there was a need to measure happiness. For this purpose we have used World Happiness Report. The World Happiness Report aims to conduct survey on happiness at the global level. The latest report (in the year 2017) ranks 155 countries based on their happiness level. The importance of the data issued in this report increases since governments, civil societies and different organizations use these data for decision-making process. The first report was published in 2012 in support of the UN High Level Meeting on happiness and well-being. The database they offer covers data starting from 2005. Happiness is taken into consideration in this paper since it tends to be the proper measure of social progress and the goal of public policy. In order to measure happiness, survey is conducted and respondents are asked to value their lives today on a 0 to 10 scale $(\boldsymbol{H A P})$, with the worst possible life as a 0 and the best possible life as a 10 (World Happiness Report, 2017).

The results explain national average life evaluations in terms of six key variables: GDP per capita, social support, healthy life expectancy, freedom to make life choices, generosity, and freedom from corruption. Taken together, these six variables explain almost three-quarters of the variation in national annual average ladder scores among countries, using data from the years 2005 to 2016 (World Happiness Report, 2017).

In addition, government consumption is expected to have an important impact on the happiness of the citizens and their social progress. This is why besides the fact that initial model estimates the impact of control of corruption on happiness, the extended model controls for the impact of government expenditure. For the purpose of this paper, government expenditure is approximated using general government final consumption expenditure (\% of GDP - GOV). GOV includes all government current expenditures for purchases of goods and services (including compensation of employees). It also includes most expenditures on national defense and security, but excludes government military expenditures that are part of government capital formation.

The data, used to estimate the relationship between HAP and CC are collected for the sample of 59 countries over the period $2007-2016$. The list of countries is given in Appendix 1. The source of the data is World Bank (World Development Indicators, 2017) and World Happiness Report, (2017). The main criterion to select a time frame was the data availability. In addition, an attempt is made to include the most recent data.

\section{Methodology}

The econometric methodology applied in this paper follows four steps. First, the panel unit root is tested for the variables. Furthermore, panel regression model is formed and estimated. In order to test the sensitivity of the results, to avoid robust errors and to estimate shortand long-run coefficients, an ARDL model is employed.

\section{Panel unit root test}

Fisher-type unit root test has been presented for understanding stationary properties of panel data in this paper. A Fisher-type test of unit root combines the $\mathrm{p}$-values from unit root tests for each cross-section $i$ to test for unit root in panel data. The Fisher test is nonparametric and distributed as chi-square with two degrees of freedom (Mahmood and Mahmood, 2016):

$$
p \lambda=-2 \sum \log _{e} \pi_{i}
$$

\section{Linear static panel data estimators}

Models will be initially estimated using linear static panel data estimators. Hausman test will be used to decide between fixed and random effects.

\section{Generalized method of moments}

To incorporate dynamics into the model, model equation can be written as an AR (1) model in general form in the following (Muslija et al., 2017):

$$
y_{i t}=\alpha_{t}+(v+1) y_{i t-1}+\beta x_{i t}+u_{i}+\varepsilon_{i t}
$$


where $y_{i t}$ is the dependent variable, $y_{i t-1}$ is the lagged value of the dependent variable, $x_{i t}$ represents a vector of explanatory variables, $u_{i}$ is individual effect, $\varepsilon_{i t}$ - error term while $\alpha_{t}$ represents the period specific intercept terms to capture changes common to all countries.

We derive the coefficients (equation (2)) using Arellano-Bover two-step GMM estimator to evaluate the joint effects of explanatory variables on the economic performance of 59 selected countries, while controlling for the potential bias due to the endogeneity of some of the regressors. Sargan test of overall validity of instruments will be conducted as well as the test of second order autocorrelation.

\section{ARDL model}

The aim of our paper is to explore the short- and long-run relationships between HAP and CC using an ARDL approach, as introduced by Pesaran et al. (1999). The ARDL model allows for the identification of short- and long-run relationships and can be categorized as an error correction model. This approach is relevant because it can test possible long-term relationships irrespective of the integration order of the variables, except that the dependent variable is constrained to be I(1). However, this technique cannot be applied when the series are integrated of order 2 (I(2)). In addition, this method offers consistent and efficient estimators because it eliminates the problems resulting from endogeneity by including lag length for both endogenous and exogenous variables. The ARDL $(p, q)$ model, including the long-term relationship between variables, can be summarized as follows (Attaoui et al., 2017):

$$
\Delta Y_{1, i t}=\alpha_{l i}+\gamma_{l i} Y_{1, i t-1}+\sum_{l=2}^{k} \gamma_{l i} X_{1, i t-1}+\sum_{j=1}^{p-1} \delta_{l i j} \Delta Y_{1, i t-j}+\sum_{j=0}^{q-1} \sum_{l=2}^{k} \delta_{l i j} \Delta X_{1, i t-j}+\varepsilon_{1, i t}
$$

where $\mathrm{Y}$ is dependent variable and $\mathrm{X}$ is the exogenous variable with $l=1,2,3,4 . \varepsilon_{i t}$ is the error term while $\Delta$ represents the first difference operator.

\section{RESULTS OF THE RESEARCH}

This section starts by presenting descriptive statistics. Table 1 summarizes the obtained results:

\section{Table 1: Descriptive Statistics}

\begin{tabular}{|l|l|l|l|}
\hline \multicolumn{4}{|l|}{ All countries } \\
\hline Statistics & HAP & CC & GOV \\
\hline mean & 5.534 & -0.203 & 14.552 \\
\hline sd & 1.051 & 0.961 & 5.053 \\
\hline max & 7.971 & 2.447 & 30.119 \\
\hline min & 2.903 & -1.523 & 2.047 \\
\hline skewness & 0.121 & 1.206 & 0.258 \\
\hline kurtosis & 2.236 & 3.445 & 2.622 \\
\hline countries & 59 & & \\
\hline
\end{tabular}

Average happiness score equals5.534 for 59 observed countries. The highest reported value of HAP equals 7.971 while the lowest equals 2.903. These results indicate huge differences in terms of happiness score as a proxy variable of social progress around the world. In terms of the control of corruption, the mean reported value equals -0.203 . The highest reported value is very far from the mean and equals 2.447 while the lowest reported value equals -1.523 . As noticed before, countries around the world face the problem of corruption but it varies among countries depending on different factors. In terms of control variable it is important to emphasize that the highest value is reported to be $30.119 \%$ while the lowest reported value equals $2.047 \%$. On average, government final consumption expenditure (\% of GDP) equals $14.552 \%$ in 59 observed countries over the period 2007-2016. The units of measurement of variables ease interpretation and there was no need for transformation.

The results of unit root test are reported in Table 2 and it is clear from the results that the null hypothesis on unit root is rejected for all variables in terms of 59 observed countries (for $1 \%$ level of significance).

Table 2: Fisher-Type Unit Root Test

\begin{tabular}{|l|l|l|l|l|l|l|l|l|}
\hline HAP & Statistic & p-value & CC & Statistic & p-value & GOV & Statistic & p-value \\
\hline $\mathrm{P}$ & 246.372 & 0.000 & $\mathrm{P}$ & 190.124 & 0.000 & $\mathrm{P}$ & 320.506 \\
\hline $\mathrm{Z}$ & -7.9205 & 0.000 & $\mathrm{Z}$ & -8.856 & 0.000 & $\mathrm{Z}$ & -10.577 & 0.000 \\
\hline $\mathrm{L}^{*}$ & -7.6323 & 0.000 & $\mathrm{~L}^{*}$ & -8.905 & 0.000 & $\mathrm{~L}^{*}$ & -10.683 & 0.000 \\
\hline $\mathrm{Pm}$ & 8.3563 & 0.000 & $\mathrm{Pm}$ & 11.148 & 0.000 & $\mathrm{Pm}$ & 12.708 \\
\hline
\end{tabular}

Source: Authors 
Table 3: Linear Static and Dynamic Panel Data Estimators

\begin{tabular}{|c|c|c|c|c|}
\hline VARIABLES & $\begin{array}{l}(1) \\
\mathrm{FE}\end{array}$ & $\begin{array}{l}(2) \\
\text { System GMM }\end{array}$ & $\begin{array}{l}\text { (3) } \\
\text { FE expanded model }\end{array}$ & $\begin{array}{l}\text { (4) } \\
\text { System GMM exp. model }\end{array}$ \\
\hline HAP L1. & & $\begin{array}{l}0.550 * * * \\
(0.0227)\end{array}$ & & $\begin{array}{l}0.551^{* * *} \\
(0.0203)\end{array}$ \\
\hline CC & $\begin{array}{l}0.312^{* * *} \\
(0.116)\end{array}$ & $\begin{array}{l}0.354 * * * \\
(0.0585)\end{array}$ & $\begin{array}{l}0.336^{* * *} \\
(0.114)\end{array}$ & $\begin{array}{l}0.339 * * * \\
(0.0446)\end{array}$ \\
\hline GOV & & & $\begin{array}{l}0.0315^{* * *} \\
(0.00817) \\
\end{array}$ & $\begin{array}{l}0.0119 * * * \\
(0.0038) \\
\end{array}$ \\
\hline Constant & $\begin{array}{l}5.597 * * * \\
(0.0272)\end{array}$ & $\begin{array}{l}2.593 * * * \\
(0.139)\end{array}$ & $\begin{array}{l}5.144^{* * *} \\
(0.121)\end{array}$ & $\begin{array}{l}2.411^{* * *} \\
(0.154)\end{array}$ \\
\hline $\begin{array}{l}\text { Hausman test } p \text { value } \\
\text { A-Bond AR (2) test } p \text { value } \\
\text { Sargan test } p \text { value } \\
\text { Observations } \\
\text { Number of id }\end{array}$ & $\begin{array}{l}0.0034 \\
590 \\
59\end{array}$ & $\begin{array}{l}0.2860 \\
0.3185 \\
531 \\
59\end{array}$ & $\begin{array}{l}0.0419 \\
590 \\
59\end{array}$ & $\begin{array}{l}0.2791 \\
0.3236 \\
531 \\
59\end{array}$ \\
\hline
\end{tabular}

Standard errors in parentheses

$* * * p<0.01, * * p<0.05, * p<0.1$

Source: Authors

Since Fisher unit root tests confirm the rejection of the null hypothesis on the existence of unit root for all variables in terms of 59 observed countries (for $1 \%$ level of significance), a panel regression model is formed and estimated. Results of Hausman test suggest fixed effects. Coefficient with CC is reported to be significant. However, robustness tests indicate that the assumptions on no-autocorrelation and homoscedasticity are not satisfied. In addition, the dynamic trend is expected as well as the endogenous relationshipbetween the observed variables. Therefore, system GMM two step estimator is suggested to deal with the aforementioned estimation issues. Table 3 summarizes the obtained results. Results of system GMM two step estimator indicate a significant positive impact of CC on HAPover the observed period. The impact of GOV is also reported to be significant. However, the impact is much weaker compared to CC.In addition, since linear static panel data estimator (fixed effects estimator) does not take into account possible endogeneity and dynamics, results are reported to be underestimated compared to those obtained using system GMM two step estimator.

The subject of interest in this paper is to analyze short- and long-run relationship between the variables of interest. For this purpose we have applied ARDL framework. Table 4 summarizes the results of long-term and short-term relationship between control of corruption and happiness. The error correction is significant (for $1 \%$ level of significance). This result proves that the process converges over the long-term. The study reveals a positive and significant relationship betweencontrol of corruption and happiness in the long-run in the initial model. However, the impact of control of corruption on happiness is not found to be significant in the short-run.

\section{Table 4: ARDL Framework}

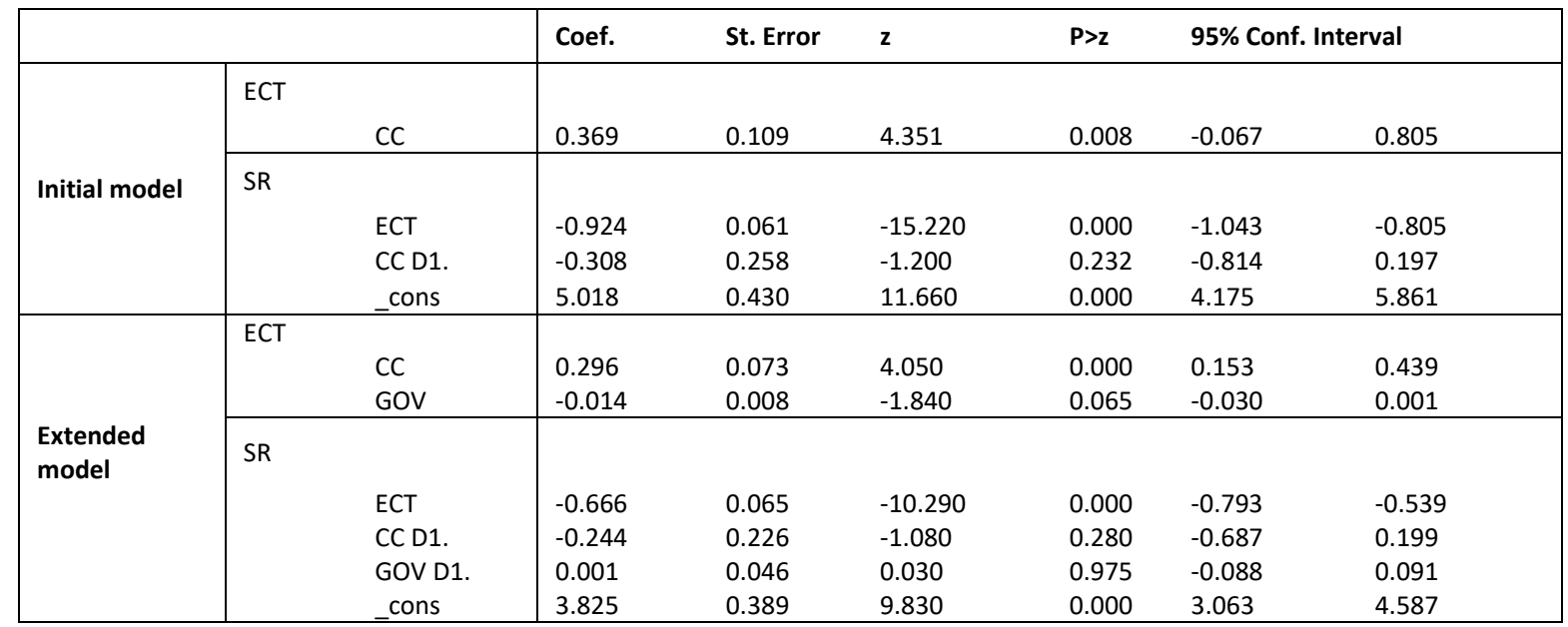

Source: Authors

In terms of the extended model it is important to notice a significant positive impact of the control of corruption on happiness in the longrun. The impact in short-run is not reported to be significant. The inclusion of the control variable decreases the size of the impact of CC. However, the sign and the significance remain the same which indicates that the initial model can be considered stable. GOV is not found to have a significant impact in the extended model in both, short- and long-run (for a $5 \%$ level of significance). 
As indicated before, the corruption does not necessarily state forever. It is possible to converge from corrupt to hones politics. Paldam (2002) indicates that the convergence process is difficult one. The results of this paper confirm these theoretical findings since the impact of the control of corruption on the social progress is found to be positive and significant only in the long-run while short-run impact is not found to be significant.

\section{CONCLUSION}

This paper attempts to fill in the gap in previous studies by examining the link betweencontrol of corruption and happiness using panel data regression models and the last available data. The relevance of control of corruption on happiness is explored for 59 countries in the world.The observed period ranges from 2007 to 2016.7

Fisher unit root test confirms the rejection of the null hypothesis on the existence of unit root for all variables in terms of 59 observed countries (for $1 \%$ level of significance). Therefore, authors have used these variables to create and estimate a panel regression model. Linear static panel data estimators are applied initially (fixed and random effects estimators). In order to decide between them, we have applied a Hausman test. Results of Hausman test suggest fixed effects. Coefficient with CC is reported to be significant. However, robustness tests indicate that the assumptions on no-autocorrelation and homoscedasticity are not satisfied. In addition, the dynamic trend is expected as well as the endogenous relationship between the observed variables. Taking this estimation issues into account, the obtained results tend not to be the most efficient.

For the purpose of this paper we suggest a system GMM two step estimator to deal with the aforementioned estimation issues. Results of system GMM two step estimator indicate a significant positive impact of CC on HAP over the observed period. The impact of GOV is also reported to be significant. However, the impact is much weaker compared to CC.Even though this estimator controls for potential endogeneity issue and dynamics, it does not provide the value of coefficient in short- and long-run.

Since, the subject of interest in this paper is to analyze short- and long-run relationship between the variables of interest, we have applied ARDL framework. The obtained results indicate thatthe error correction is significant (for $1 \%$ level of significance). This result proves that the process converges over the long-term. The study reveals a positive and significant relationship betweencontrol of corruption and happiness in the long-run in the initial model. However, the impact of control of corruption on happiness is not found to be significant in the short-run.

In terms of the extended model it is important to notice a significant positive impact of the control of corruption on happiness in the longrun. The impact in short-run is not reported to be significant. The inclusion of the control variable decreases the size of the impact of CC. However, the sign and the significance of the results remain the same which indicates that the initial model can be considered stable. GOV is not found to have a significant impact in the extended model in both, short- and long-run (for a $5 \%$ level of significance). The results of this paper confirm that the convergence process from corrupt to hones politics is long and complex, since the impact of the control of corruption on the social progress is found to be positive and significant only in the long-run while short-run impact is not found to be significant.

\section{REFERENCES}

Aidt, S. T. (2009). Corruption, institutions and economic development. Oxford Review of Economic Policy, vol. 25, no. 2, p. 271-291, https://doi.org/10.1093/oxrep/grp012

Attaoui, I., Ammpurim B., Gargouri, I. (2017). Causality links among renewable energy consumption, CO2 emissions, and economic growth in Africa: evidence from a panel ARDL-PMG approach. Environmental Science and Pollution Research, vol. 24, no. 14, p. 1306- 13048, https://doi.org/10.1007/s11356-017-8850-7

Balboa, J., Medalla, E. M. (2006). Anti-corruption and governance: the Philippine experience. APEC Study Center Consortium Conference.2006/ASCC/014.

Blackburn, K., Bose, N., Haque E. M. (2006). The incidence and persistence of corruption in economic development. Journal of Economic Dynamics and Control, vol. 30, p. 2447-2467.

Clark, A. E., Fléche, S., Senik, C. (2014). Economic growth evens-out happiness: evidence from six surveys. SOEPpapers on Multidisciplinary Panel Data Research, no. 633.

Fereidouni, H. G., Najdi, Y., Amiri, R. E. (2013). Do governance factors matter for happiness in the MENA region?. International Journal of Social Economics, vol. 40, no. 12, p. 1028-1040 https://doi.org/10.1108/IJSE-11-2012-0208

Kéita, K. (2011). Essays on corruption and economic growth: a theoretical and empırical evidence. University of Tampere, Finland .

Klitgaard, R. (1998). Strategies against corruption. Agencia Española de Cooperación Internacional http://citeseerx.ist.psu.edu/viewdoc/download?doi=10.1.1.454.9660\&rep=rep1\&type=pdf.

Knott, J. H. (2012). Corruption, social inefficiency, and economic development in China and the United States. Lien China Development Forum, China.

Mahmood, M., Mahmood, E. (2016). Foreign direct investment, exports and economic growth: evidence two panels of developing countries. Economic Research-Ekonomska Istraživanja, vol. 29, no. 1, p. 938-949. 
Muslija, A., Satrovic, E., Unver Erbas, C. (2017). Panel analysis of tourism -economic growth nexus. International Journal of Economic Studies, vol. 3, no. 4, p. 535-545.

Paldam, M. (2002). The cross-country pattern of corruption: economics, culture and the seesaw dynamics. European Journal of Political Economy, vol. 18, no. 2, p. 215-240.

Pesaran M.H., Shin Y., Smith R.P. (1999). Pooled mean group estimation of dynamic heterogeneous panels. J Am Stat Assoc, vol. 94, p.621634.

Popova, Y., Podolyakina, N. (2014). Pervasive impact of corruption on social system and economic growth. Procedia - Social and Behavioral Sciences, vol. 110, p. 727-737, doi: 10.1016/j.sbspro.2013.12.917.

Shera, A., Dosti, B., Grabova, P. (2014). Corruption impact on economic growth: an empirical analysis. Journal of Economic Development, Management, IT, Finance and Marketing, vol. 6, no. 2, p. 57-77.

Voskanyan, F. (2000). A study of the effects of corruption on economic and political development of Armenia. American University of Armenia.

Weder, B. (2002). Institutions, corruption and development and their ramifications for international cooperation. UNU Millennium Series, Tokyo: United Nations University Press. Working Papers, 02/213.

World Happiness Report. (2017). Source: http://worldhappiness.report/wp-content/uploads/sites/2/2017/03/HR17.pdf 